\title{
Meat quality and fatty acid profile of M. longissimus dorsi of growing bulls under insulated, uninsulated and outdoor housing conditions
}

\author{
Arto Huuskonen $^{1 *}$, Erkki Joki-Tokola ${ }^{1}$, Markku Honkavaara ${ }^{2}$, Leena Tuomisto ${ }^{3}$ and Risto Kauppinen ${ }^{4}$ \\ ${ }^{1}$ MTT Agrifood Research Finland, Animal Production Research, Tutkimusasemantie 15, FI-92400 Ruukki, Finland, \\ "email: arto.huuskonen@mtt.fi \\ ${ }^{2}$ Finnish Meat Research Institute, PO Box 56, FI-13101, Hämeenlinna, Finland \\ ${ }^{3}$ MTT Agrifood Research Finland, Animal Production Research, Halolantie 31A, FI-92400 Maaninka, Finland \\ ${ }^{4}$ Savonia University of Applied Sciences, PO Box 72, FI-74101 Iisalmi, Finland
}

The objective of the present study was to compare the colour, chemical composition, meat quality and fatty acid profile of the longissimus dorsi (LD) muscle of growing bulls housed in an insulated tie-stall, an uninsulated barn or a forest paddock. Two housing experiments were conducted at the North Ostrobothnia Research Station of MTT Agrifood Research Finland in Ruukki (644ㄴ $\left.{ }^{\prime} \mathrm{N}, 25^{\circ} 15^{\prime} \mathrm{E}\right)$. The first experiment was conducted from November 1999 to October 2000 and comprised 30 Hereford bulls, the second from November 2000 to December 2001 with 30 Ayrshire bulls. In both experiments the bulls were divided into six groups of five animals according to live weight and the groups were randomly allotted to one of three treatments: tie-stall in an insulated barn (IB bulls, ten animals/individual stall), uninsulated barn (UB bulls, five animals/pen, two pens) and forest paddock (PAD bulls, five animals/paddock, two paddocks). Nine carcasses from experiment 1 (three/treatment) and twelve from experiment 2 (four/treatment) were randomly selected for meat quality analyses. After slaughter, the carcasses were cooled for $24 \mathrm{~h}$ at $2{ }^{\circ} \mathrm{C}$ and $\mathrm{LD}$ samples were taken by complete cross-section between the 12th and 13th ribs. The results were calculated across the two experiments and analysed as one data. There were no differences between housing environments in temperature or $\mathrm{pH}$ of the $\mathrm{LD}$ or meat moisture, fat or protein composition of the LD. Instead, the myoglobin content of the LD was $21 \%$ higher in PAD bulls than in IB bulls $(p<0.05)$. Between IB and UB bulls there was no difference in meat myoglobin content and there were no significant $(p<0.05)$ differences between housing environments in the colour of the LD. However, the muscle tended to be $6 \%$ lighter (L-value) in IB bulls than in PAD bulls $(p=0.09)$. There were no significant differences in shear force or sensory analysis (tenderness, juiciness, overall flavour) between treatments. The LD of the PAD bulls contained a higher proportion of 18:2 and 18:3 fatty acids compared to that of IB bulls $(p<0.05)$. There were no significant differences in the saturated fatty acid (SFA) or monounsaturated fatty acid proportions of the LD between treatments. Instead, the polyunsaturated fatty acid (PUFA) proportion of the LD was $34 \%$ higher in PAD bulls than in IB bulls $(p<0.05)$. The PUFA:SFA ratio was higher in PAD bulls than in IB bulls $(p<0.05)$ but there was no difference in the PUFA:SFA ratio between UB and IB bulls. In conclusion, there were no important effects of housing system on the meat quality characteristics of the LD, although according to meat fatty acid profiles, outdoor housed bulls produced meat with a higher PUFA:SFA ratio than tethered bulls in an insulated barn.

Key-words: Beef production, bulls, housing, meat quality, fatty acids

(C) Agricultural and Food Science

Manuscript received November 2009 
Vol. 19(2010): 214-222.

\section{Introduction}

Rising housing costs have created a demand for inexpensive winter housing systems for beef cattle in Finland (e.g. Manninen et al. 2008), and one way of reducing these costs is to overwinter growing cattle outdoors. For example, in Taivalkoski, North-Eastern Finland ( $\left.65^{\circ} 34^{\prime} \mathrm{N}, 28^{\circ} 14^{\prime} \mathrm{E}\right)$, 400-600 growing animals are every year raised on very extensive forested land ( 0.5 animal unit ha-1) (Uusi-Kämppä et al. 2007). Huuskonen et al. (2009) and Tuomisto et al. (2009) reported that finishing bulls can be overwintered outdoors with reasonable live weight gains in Northern Finland without warm housing facilities. However, compared with the tie-stall system, the energy expenditure of walking and other exercise increases in outdoor housing systems, which means increased energy intake and reduced feed conversion rates (Huuskonen et al. 2009, Tuomisto et al. 2009). Behavioural studies (Tuomisto et al. 2008, 2009) have shown that the time budgets and diurnal rhythms of the bulls housed in an uninsulated barn and in forest paddocks were quite similar. It seemed that season and/or age of the bulls had a greater impact on the bulls' behaviour than the housing environment itself. However, the effects of these types of housing on meat quality traits have not been published earlier.

Meat colour is an important determinant of the visual appearance of meat, with light beef often being preferred, although some consumers may favour dark beef by associating this appearance with a more natural production method (Razminowicz et al. 2006). Priolo et al. (2001) concluded that beef from animals finished on pasture is darker than beef from animals finished on concentrate. On the contrary, Muir et al. (1998a) reported that the type of feeding system had no effect on lean meat colour. In general, it is difficult to evaluate the effects that affect beef colour, because more than one factor plays an important role. Some authors (Muir et al. 1998b, Vestergaard et al. 2000) consider the physical activity of the animal to affect meat colour.

Many studies (e.g. French et al. 2000, Realini et al. 2004) have demonstrated that there are differences in the intramuscular fatty acid composition of growing cattle offered grazed grass or concentratebased diets. The effects of diet and physical activity are, however, often partly confounded in meat quality studies. In order to determine the specific effects of diet and housing environment on meat quality, the animals should be fed in different housing environments but with the same diets, or vice versa. Therefore, the objective of the present study was to compare the colour, chemical composition, meat quality and fatty acid profile of the longissimus dorsi (LD) muscle of growing bulls housed in an insulated tie-stall, uninsulated barn or in a forest paddock on similar diets. Animal performance and carcass characteristics results have been reported earlier by Huuskonen et al. (2009) and Tuomisto et al. (2009).

\section{Material and methods}

\section{Animals and housing environments}

Two housing experiments were conducted at the North Ostrobothnia Research Station of MTT Agrifood Research Finland in Ruukki (644ㄴ' $\mathrm{N}$, $25^{\circ} 15^{\prime} \mathrm{E}$ ). The experimental procedures were evaluated and approved by the Animal Care and Use Committee of MTT Agrifood Research Finland. The first experiment was conducted from November 1999 to October 2000, and comprised 30 Hereford bulls. The bulls were born in spring 1999 at the Tohmajärvi Suckler Cow Barn of MTT Agrifood Research Finland $\left(62^{\circ} 20^{\prime} \mathrm{N}, 30^{\circ} 15^{\prime} \mathrm{E}\right)$ and spent their first summer with their dams on pasture. In autumn 1999, the bulls were weaned and transferred to the North Ostrobothnia Research Station. In November 1999, the bulls (age $6.8 \pm 0.5$ (mean \pm SD) months; live weight (LW) $285 \pm 35 \mathrm{~kg}$ ) were divided into six groups of five animals according to LW and the groups were randomly allotted to one of three treatments: tie-stall in an insulated barn (IB bulls, ten animals/individual stall), uninsulated barn (UB bulls, five animals/pen, two pens) and forest paddock (PAD bulls, five animals/paddock, two paddocks). 


\section{AGRICULTURAL AND FOOD SCIENCE}

\section{Huuskonen, A. et al. Meat quality of bulls under different housing conditionsl}

The second experiment was conducted from November 2000 to December 2001 and comprised 30 Ayrshire bulls purchased from local dairy farms when they were $44 \pm 8 \mathrm{~kg} \mathrm{LW}$ and $14 \pm 5$ days old. During the pre-experimental period from June 2000 to November 2000, the calves were housed in an uninsulated barn in partly straw-bedded pens (five calves/pen, $3.2 \mathrm{~m}^{2} /$ calf). In November 2000, when the bulls were $5.4 \pm 0.8$ months old, they were divided into six groups of five animals balanced according to LW. These groups were randomly allotted to one of three treatments: tie-stall in an insulated barn (IB bulls, ten animals/individual), uninsulated barn (UB bulls, five animals/pen, two pens) and forest paddock (PAD bulls, five animals/paddock, two paddocks). The climatic data during these two experiments have been described by Huuskonen et al. (2009) and Tuomisto et al. (2009).

The IB bulls were placed in an insulated barn in adjacent tie-stalls. The width of the stalls was 70-90 $\mathrm{cm}$ for the first four months and $113 \mathrm{~cm}$ until the end of the experiment. The bulls were tied with a collar around the neck and a chain of $50 \mathrm{~cm}$ attached to a horizontal bar $40-55 \mathrm{~cm}$ above the floor. The floor surface was solid concrete under the forelegs and metal grids under the hind legs. No bedding was used on the floor. Each bull had its own water bowl.

The UB bulls were placed in an uninsulated barn into adjacent pens $\left(4 \times 8 \mathrm{~m}, 6.4 \mathrm{~m}^{2} /\right.$ bull $)$. The uninsulated barn was covered with a roof and it had solid wooden walls on all sides except for the front side that was left open. The rear half of the pen area was a straw-bedded lying area and the fore half was a feeding area with a solid concrete floor. A feeding trough was situated on the front side of the pen, and there was $0.8 \mathrm{~m}$ of feeding space/bull at the feeding trough. There was one heated water bowl between the pens offering water for all ten pen bulls. The concrete feeding area was cleaned three times a week and the bedded lying area was cleaned monthly. Barley straw was added to the bedded lying area three times a week.

The PAD bulls were placed in two adjacent forest paddocks $\left(50 \times 100 \mathrm{~m}, 1000 \mathrm{~m}^{2} /\right.$ bull $)$ built up in young forest. The vegetation of the paddock area consisted mostly of young conifer trees mixed with some birches. The ground was covered with twigs and grass. The vegetation and soil texture of the paddock area have been described in detail by Uusi-Kämppä et al. (2007). A wooden fence separated the paddocks from each other. The other three sides of the paddocks were fenced with an electric fence. Between the two paddocks there was a simple, roofed, three-walled shed $(8 \times 4 \mathrm{~m})$ available for the bulls. The floor of this shed was deep strawbedded. In front of the shed was a feeding area ( 8 $\times 4 \mathrm{~m}$ ) with a solid concrete floor. The shed as well as the feeding area were split in two with wooden walls so that each group of paddock bulls had access to a shed area of $4 \times 4 \mathrm{~m}$ and a feeding area of $4 \times 4 \mathrm{~m}$. A feeding trough was situated in front of the feeding area with $1.0 \mathrm{~m}$ of feeding space/bull. There was one heated water bowl in the feeding area offering water for all the ten paddock bulls. The concrete-floored feeding area was cleaned once a week. Barley straw was added to the bedded lying area three times a week in winter and once a week during the summer.

In both experiments, all bulls were fed ad libitum a total mixed ration (TMR) which was composed of grass silage and rolled barley. The daily ration also included a mineral mixture (Feedmix Ltd., Finland: Tähkä Apekivennäinen) 150 g/animal. A vitamin mixture (Suomen Rehu, Finland: Xylitol ADE-Vita) was given at $50 \mathrm{~g} /$ animal weekly. Feeding regimes, feeds and feed intake data are described in detail by Huuskonen et al. (2009) and Tuomisto et al. (2009).

\section{Meat quality measurements}

After slaughter in a commercial meat plant, carcasses were weighed hot. Cold carcass weight was estimated as 0.98 of hot carcass weight. Dressing proportions were calculated from the ratio of cold carcass weight to final live weight. Carcass conformation and carcass fatness were determined according to the EUROP classification (Commission of the European Communities 1982). Nine carcasses from experiment 1 (3/treatment) and twelve carcasses from experiment 2 (4/treatment) were randomly selected for meat quality analyses. So there were seven carcasses/ 
Vol. 19(2010): 214-222.

treatment for meat quality measurements. After slaughter, the carcasses were cooled for $24 \mathrm{~h}$ at $2{ }^{\circ} \mathrm{C}$. The $\mathrm{pH}$ and temperature of LD were measured 1, 5 and $24 \mathrm{~h}$ after slaughter. LD samples were taken by complete cross-section between the 12th and 13th ribs. Samples of LD were vacuum packaged and later analysed for moisture, protein, fat and myoglobin concentrations, instrumental colour, Warner-Bratzler shear force, long-chain fatty acids and for subjective tenderness, juiciness and overall flavour (sensory analysis). Fat and moisture concentrations were determined using an integrated microwave moisture and methylene chloride fat extraction method (Bostian et al. 1985) on a CEM moisture/solids analyser. Protein was determined by the method of Sweeney and Rexroad (1987) using a LECO protein analyser. Instrumental colour measurements were recorded after 14 days ageing for L* (lightness; 0: black, 100: white), a* (redness/greenness; positive values: red, negative values: green), and $b^{*}$ (yellowness/ blueness; positive values: yellow; negative values: blue) using A Minolta ChromaMeter Cr200 (Minolta Camera Co., Ltd., Osaka, Japan). The bloom time was half an hour. Minolta CR200 was calibrated to standard white plate. CIE Standard Illuminant D65 conditions were used for measurements. Myoglobin $(\mathrm{Mb})$ concentration was measured as described by Hornsey (1956).

Steaks $(2.5 \mathrm{~cm})$ for tenderness determinations were vacuum packaged, stored in a cooler at 2 ${ }^{\circ} \mathrm{C}$ and frozen after 21 days of ageing for subsequent Warner-Bratzler shear force determination. Warner-Bratzler shear force was measured using an Instron Universal 1011 testing machine with a Warner-Bratzler shearing device on $1 \mathrm{~cm}^{2}$ blocks cut parallel to the direction of the muscle fibres from the sample used in the determination of cooking loss. The crosshead speed was $150 \mathrm{~mm} \mathrm{~min}^{-1}$. The fatty acids methyl esters (FAMEs) were analyzed in a gas chromatograph (Varian, USA) equipped with a flame ionization detector and a fused silica capillary column CP-7420 (100 m, $0.25 \mathrm{~mm}$ and $0.39 \mu$ o.d., Varian, USA) Select Fame. Column temperature was programmed at $165^{\circ} \mathrm{C}$ for $18 \mathrm{~min}$, $180^{\circ} \mathrm{C}\left(30^{\circ} \mathrm{C} \mathrm{min}-1\right)$ for $22 \mathrm{~min}$, and $240{ }^{\circ} \mathrm{C}\left(15^{\circ} \mathrm{C}\right.$ $\mathrm{min}^{-1}$ ) for $30 \mathrm{~min}$, with 45 -psi pressure. The injector and detector were kept at $220{ }^{\circ} \mathrm{C}$ and $245^{\circ} \mathrm{C}$, respectively. The gas fluxes (White Martins) used were: $1.4 \mathrm{ml} \mathrm{min}^{-1}$ for the carrier gas (H2); $30 \mathrm{ml}$ $\mathrm{min}^{-1}$ for the make-up gas (N2) and $30 \mathrm{ml} \mathrm{min}^{-1}$ and $300 \mathrm{ml} \mathrm{min}^{-1}$ for $\mathrm{H} 2$ and the synthetic flame gas, respectively. Sample injection split mode was 1/80. Fatty acids were identified by comparing the relative retention times of FAME peaks of the samples with fatty acids methyl ester standards from Sigma (USA) by spiking samples with standard. The peak areas were determined by Star software (Varian). The data were expressed as percentages of the normalized area of fatty acids (Rowe et al. 1999). Sensory analysis (tenderness, juiciness and overall flavour) was performed after 14 days of ageing by a six member, in-house trained panel on steaks grilled to an internal temperature of $70{ }^{\circ} \mathrm{C}$ according to the American Meat Science Association Guidelines (AMSA 1978). Panellists were asked to assess the samples for the following attributes: tenderness (scale $1-7 ; 1=$ extremely tough, 7=extremely tender), moistness/juiciness (scale 1-7; 1=extremely dry, $7=$ extremely juicy), overall flavour (scale 1-7; $1=$ very poor, $7=$ very good).

\section{Statistical analyses}

The meat quality results were calculated across the two experiments and are shown as least squares means. Both experiments were merged and analysed as one data due to small sample size/experiment. Three carcasses/treatment in experiment 1 and four carcasses/treatment in experiment 2 were analysed for meat quality. When experiments were merged there were seven carcasses/treatment for meat quality measurements and it was realistic to do statistical testing. The statistical analyses of the data were performed using the SAS general linear models procedure (SAS Institute Inc., Cary, NC, USA). The variables were measured individually and the following statistical model was used to analyse the data:

$\mathrm{Y}_{\mathrm{ijkl}}=\mu+\alpha_{\mathrm{i}}+\beta_{\mathrm{j}}+(\alpha \beta)_{\mathrm{ij}}+\chi_{\mathrm{ijk}}+\mathrm{e}_{\mathrm{ijkl}}$ 
Huuskonen, A. et al. Meat quality of bulls under different housing conditionsl

where $\mu$ is the overall mean and $\mathrm{e}_{\mathrm{ijk}}$ is the random error term. $\alpha$ and $\beta$ are the effects of housing environment and experiment. $\chi_{\mathrm{ijk}}$ is the effect of group within environment-by-experiment combination and it was used as an error term when differences between housing environments were tested.

Normality of residuals was checked using graphical methods: box-plot and scatter plot of residuals and fitted values. Differences between the housing environments were compared using an $a$ priori test (Dunnett's test) so that IB was used as a control environment and comparison of the environments was based on IB.

\section{Results}

The average temperature of the LD of bulls was 38.5, 19.8 and $3.8^{\circ} \mathrm{C}$ at $1 \mathrm{~h}, 5 \mathrm{~h}$ and $24 \mathrm{~h}$ after slaughter, respectively, and the average $\mathrm{pH}$ was 6.6, 5.8 and 5.6 ${ }^{\circ} \mathrm{C}$, respectively. There were no differences between housing environments either in temperature or $\mathrm{pH}$ of the LD (Table 1). There were no differences in meat moistness, fat or protein composition either. The average moistness, fat and protein compositions of LD were 737, 36 and $217 \mathrm{~g} \mathrm{~kg}^{-1}$, respectively. Instead, the myoglobin content of LD was $21 \%$

Table 1. Meat quality of Musculus longissimus dorsi of growing bulls housed in an insulated barn (IB), uninsulated barn (UB) and forest paddock (PAD).

\begin{tabular}{|c|c|c|c|c|c|c|}
\hline & \multirow[b]{2}{*}{ IB } & \multirow[b]{2}{*}{ UB } & \multirow[b]{2}{*}{ PAD } & \multirow[b]{2}{*}{$\mathrm{SEM}^{\mathrm{b}}$} & \multicolumn{2}{|c|}{$p$ value $^{\mathrm{a}}$} \\
\hline & & & & & $\mathrm{C} 1$ & $\mathrm{C} 2$ \\
\hline \multicolumn{7}{|l|}{ Temperature, ${ }^{\circ} \mathrm{C}$} \\
\hline $1 \mathrm{~h}$ after slaughter & 38.3 & 39.0 & 38.2 & 0.48 & 0.31 & 0.87 \\
\hline $5 \mathrm{~h}$ after slaughter & 20.3 & 19.9 & 19.2 & 1.10 & 0.84 & 0.51 \\
\hline $24 \mathrm{~h}$ after slaughter & 4.0 & 3.8 & 3.7 & 0.43 & 0.71 & 0.60 \\
\hline \multicolumn{7}{|l|}{$\mathrm{pH}$} \\
\hline 1h after slaughter & 6.6 & 6.6 & 6.5 & 0.09 & 0.95 & 0.28 \\
\hline $5 \mathrm{~h}$ after slaughter & 5.8 & 5.9 & 5.8 & 0.07 & 0.48 & 0.65 \\
\hline $24 \mathrm{~h}$ after slaughter & 5.6 & 5.6 & 5.6 & 0.04 & 0.98 & 0.48 \\
\hline \multicolumn{7}{|c|}{ Chemical composition, $\mathrm{g} \mathrm{kg}^{-1}$} \\
\hline Moisture & 736 & 737 & 738 & 4.7 & 0.98 & 0.80 \\
\hline Fat & 39 & 36 & 33 & 6.0 & 0.73 & 0.52 \\
\hline Protein & 215 & 217 & 218 & 1.8 & 0.36 & 0.22 \\
\hline Myoglobin, $\mathrm{mg} \mathrm{g}^{-1}$ & 9.5 & 10.5 & 11.5 & 0.63 & 0.26 & 0.04 \\
\hline \multicolumn{7}{|l|}{ Colour at $14 \mathrm{~d}$} \\
\hline “L” (lightness) & 40.0 & 39.1 & 37.8 & 0.88 & 0.49 & 0.09 \\
\hline "a" (redness) & 27.6 & 28.9 & 29.6 & 0.87 & 0.32 & 0.12 \\
\hline "b" (yellowness) & 9.8 & 10.1 & 10.2 & 0.57 & 0.72 & 0.62 \\
\hline Shear force at $21 \mathrm{~d}, \mathrm{~kg}$ & 7.2 & 7.0 & 7.4 & 0.48 & 0.80 & 0.74 \\
\hline \multicolumn{7}{|l|}{ Sensory analysis } \\
\hline Tenderness $^{c}$ & 5.3 & 5.2 & 4.9 & 0.25 & 0.74 & 0.25 \\
\hline Juiciness $^{\mathrm{d}}$ & 4.7 & 4.7 & 4.7 & 0.16 & 0.98 & 0.75 \\
\hline Overall flavour ${ }^{\mathrm{e}}$ & 5.0 & 4.6 & 4.8 & 0.22 & 0.21 & 0.59 \\
\hline
\end{tabular}

${ }^{a}$ Differences between housing environments were compared using the a priori test (Dunnett's test) so that IB was used as a control. C1: IB vs. UB; C2: IB vs. PAD.

${ }^{\mathrm{b}}$ Standard error of mean.

c Scale $1-7 ; 1=$ extremely tough, $7=$ extremely tender.

${ }^{\mathrm{d}}$ Scale $1-7 ; 1=$ extremely dry, $7=$ extremely juicy.

${ }^{\mathrm{e}}$ Scale $1-7 ; 1=$ very poor, $7=$ very good. 
Vol. 19(2010): 214-222.

higher in the PAD bulls than in IB bulls $(p<0.05)$. Between the IB and UB bulls there was no difference in meat myoglobin content (Table 1).

The mean muscle "L", "a" and "b" values were 39.0, 28.7 and 10.0, respectively. There were no significant $(p<0.05)$ differences between housing environments in the colour of the LD (Table 1). However, the muscle lightness ( $\mathrm{L}$ value) tended to be $6 \%$ higher in the IB bulls than in the PAD bulls $(p=0.09)$. Furthermore, there were no significant differences in shear force or sensory analysis (tenderness, juiciness, overall flavour) between treatments.
The LD of the PAD bulls contained a higher proportion of 18:2 and 18:3 fatty acids compared to that of the IB bulls $(p<0.05)$ (Table 2). In addition, there was a tendency for the LD of the PAD bulls to have a higher proportion of 20:4 and 22:5 fatty acids compared to the LD of the IB bulls ( $p$ $=0.09)$. The LD muscle of the UB bulls tended to contain a higher proportion of $12: 0$ and $18: 3$ fatty acids compared to that of the IB bulls ( $p=0.07$ ). There were no significant differences in the SFA or MUFA proportions of the LD of bulls between treatments. Instead, the PUFA proportion of the LD was $34 \%$ higher in the PAD than in the IB bulls $(p$

Table 2. Fatty acid profiles (\% of total fatty acids) of Musculus longissimus dorsi of growing bulls housed in an insulated barn (IB), uninsulated barn (UB) and forest paddock (PAD).

\begin{tabular}{|c|c|c|c|c|c|c|}
\hline \multirow[b]{2}{*}{ Fatty acid } & \multirow[b]{2}{*}{ IB } & \multirow[b]{2}{*}{ UB } & \multirow[b]{2}{*}{ PAD } & \multirow[b]{2}{*}{ SEM $^{\mathrm{b}}$} & \multicolumn{2}{|c|}{$p$ value $^{\mathrm{a}}$} \\
\hline & & & & & $\mathrm{C} 1$ & $\mathrm{C} 2$ \\
\hline $12: 0$ & 0.06 & 0.10 & 0.07 & 0.016 & 0.07 & 0.53 \\
\hline $14: 0$ & 2.84 & 3.07 & 2.81 & 0.177 & 0.37 & 0.91 \\
\hline $16: 0$ & 27.16 & 27.46 & 26.16 & 0.773 & 0.79 & 0.37 \\
\hline $16: 1 n-7$ & 3.06 & 3.19 & 2.79 & 0.175 & 0.61 & 0.29 \\
\hline $17: 0$ & 0.84 & 0.90 & 0.91 & 0.034 & 0.25 & 0.15 \\
\hline 18:0 & 16.99 & 16.66 & 17.84 & 0.664 & 0.73 & 0.37 \\
\hline $18: 1 n-9$ & 38.70 & 36.33 & 37.03 & 1.184 & 0.17 & 0.33 \\
\hline $18: 2 n-6$ & 2.19 & 2.64 & 2.90 & 0.218 & 0.16 & 0.03 \\
\hline $18: 3 n-3$ & 0.53 & 0.66 & 0.70 & 0.048 & 0.07 & 0.02 \\
\hline 20:0 & 0.13 & 0.14 & 0.17 & 0.019 & 0.60 & 0.13 \\
\hline $20: 1 n-9$ & 0.20 & 0.16 & 0.19 & 0.023 & 0.20 & 0.66 \\
\hline $20: 2 n-6$ & 0.01 & 0.04 & 0.01 & 0.016 & 0.24 & 0.99 \\
\hline $20: 4 n-6$ & 0.37 & 0.47 & 0.51 & 0.056 & 0.22 & 0.09 \\
\hline $22: 5 n-3$ & 0.14 & 0.19 & 0.20 & 0.023 & 0.20 & 0.09 \\
\hline Unknown fatty acid & 6.81 & 7.96 & 7.79 & 0.483 & 0.11 & 0.17 \\
\hline $\mathrm{SFA}^{\mathrm{c}}$ & 48.03 & 48.33 & 47.91 & 1.225 & 0.86 & 0.95 \\
\hline MUFA $^{\mathrm{d}}$ & 41.94 & 39.71 & 40.00 & 1.260 & 0.23 & 0.29 \\
\hline PUFA $^{\mathrm{e}}$ & 3.20 & 4.00 & 4.30 & 0.326 & 0.10 & 0.03 \\
\hline PUFA:SFA & 0.07 & 0.08 & 0.09 & 0.007 & 0.15 & 0.04 \\
\hline MUFA:SFA & 0.88 & 0.83 & 0.84 & 0.047 & 0.44 & 0.60 \\
\hline (MUFA+PUFA):SFA & 0.95 & 0.91 & 0.94 & 0.048 & 0.58 & 0.88 \\
\hline
\end{tabular}

${ }^{a}$ Differences between housing environments were compared using the a priori test (Dunnett's test) so that IB was used as a control. C1: IB vs. UB; C2: IB vs. PAD.

${ }^{\mathrm{b}} \mathrm{Standard}$ error of mean.

'Saturated fatty acids.

${ }^{\mathrm{d}}$ Monounsaturated fatty acids.

ePolyunsaturated fatty acids. 
Huuskonen, A. et al. Meat quality of bulls under different housing conditionsl

$<0.05)$. In addition, there was a tendency for the PUFA proportion of the LD to be $8 \%$ higher in the UB bulls than in the IB bulls $(p<0.10)$. The PUFA:SFA ratio was higher in the PAD than in the IB bulls $(p<0.05)$ but there was no difference in the PUFA:SFA ratio between the UB and IB bulls (Table 2).

\section{Discussion}

Animal performance and carcass characteristics results under different housing conditions have been reported in detail earlier by Huuskonen et al. (2009) and Tuomisto et al. (2009). However, for better understanding of the results in this paper, some major results concerning the animals and carcasses are mentioned here. Hereford bulls were slaughtered in October 2000, when the bulls were 18.3 months of age and $772 \mathrm{~kg} \mathrm{LW}$. The mean carcass weight was $414 \mathrm{~kg}$, and there were no significant differences between the treatments in age, final LW or carcass weight. Huuskonen et al. (2009) reported that the live weight gain (LWG) of the UB bulls was 7\% higher than that of the IB bulls (1436 vs. $1339 \mathrm{~g}$ $\mathrm{d}^{-1}$ ) and there was a tendency that the LWG of the PAD bulls was $6 \%$ higher than that of the IB bulls (1414 vs. $1339 \mathrm{~g} \mathrm{~d}^{-1}$ ). The carcass conformation score of the PAD bulls was $23 \%$ higher than that of the IB bulls, but there were no significant effects of treatments on the dressing proportion or carcass fat score of Hereford bulls.

Ayrshire bulls were slaughtered in December 2001, when the bulls were 18.6 months of age and $602 \mathrm{~kg}$ LW. The mean carcass weight was $308 \mathrm{~kg}$, and there were no significant differences between the treatments in age, final LW or carcass weight. Tuomisto et al. (2009) reported that the LWG of the PAD bulls tended to be $12 \%$ lower than that of the IB bulls ( 972 vs. $1090 \mathrm{~g} \mathrm{~d}^{-1}$ ). There were no effects of housing environment on the dressing proportion of Ayrshire bulls. The carcass fat score of both UB and PAD bulls was $32 \%$ lower than that of the IB bulls. The carcass conformation score of the UB bulls was $14 \%$ higher than the corresponding value of the IB bulls but there were no significant differences in the carcass conformation score between the IB and PAD bulls.

In general, there were no important effects of housing system on the meat quality characteristics of the LD. These results are broadly in agreement with those by Lowe et al. (2001) and Dunne et al. (2008) that floor or accommodation type has no significant effect on the meat quality of finishing cattle. For example, Dunne et al. (2008) raised Charolais crossbred steers either outside on (18 $\mathrm{m}^{2} /$ head) or inside in the same naturally-ventilated building in slatted-floor pens $\left(2.5 \mathrm{~m}^{2} / 500 \mathrm{~kg} \mathrm{LW}\right)$ or straw-bedded pens $\left(4 \mathrm{~m}^{2} /\right.$ head $)$. Housing environment had no effect on the chemical composition (moisture, protein, fat), shear force or sensory analysis (tenderness, juiciness, flavour, firmness, chewiness, texture, acceptability) of meat (Dunne et al. 2008). Lee et al. (2008) studied the effect of housing system (loose housing and tethering) on the carcass and meat qualities of Hanwoo (Korean cattle) bulls and reported no effect of housing on sensory analysis, $\mathrm{pH}$ or shear force. However, the fat content of meat from loose housed bulls was significantly lower and the moisture content was higher than those of tethered bulls (Lee, et al. 2008), which disagrees with the results of our study.

In the present experiment, the myoglobin content of the LD was higher in the PAD bulls than in the IB bulls. In general, myoglobin is unfortunately seldom measured in beef cattle experiments. However, according to Essén-Gustavsson (1996), the muscles of active animals contain more myoglobin than those of their inactive counterparts, but differences are also seen between muscles depending on the extent of their involvement in activity. Also Varnam and Sutherland (1995) hypothesized that pasture-fed animals have more muscle myoglobin due to more activity pre-slaughter than their feedlot counterparts. Miller (1994) concluded that myoglobin content is directly related to final muscle colour and high-use muscles have higher myoglobin content due to the need for myoglobin to store and deliver oxygen in the muscle. In agreement with the present study Vestergaard et al. (2000) reported that the concentration of heme pigment in 
Vol. 19(2010): 214-222.

LD muscle of extensively-reared bulls was higher than corresponding value in LD of intensivelyreared bulls. The concentration of heme pigment does express the same as myoglobin measuring the total heme, which includes myoglobin and haemoglobin captured in the capillaries in the meat.

The muscle lightness ( $\mathrm{L}$ value) tended to be higher in the IB than in the PAD bulls. So the results of our experiment support the hypothesis suggested by Muir et al. (1998b), Vestergaard et al. (2000) and Huuskonen et al. (2010) that enhanced activity levels would result in darker muscle. Also Dunne et al. (2008) reported that the LD muscle of steers raised outside $\left(18 \mathrm{~m}^{2} /\right.$ head $)$ was darker than the LD of steers raised in straw-bedded pens (4 m²/head). Similarly, Jensen and Oksama (1996) concluded that housing environment influenced the muscle lightness of young Danish Friesian and Danish Jersey bulls when loose-housed and tie-stall bulls were compared. On the contrary, Dunne et al. (2005) concluded that exercise had no effect on muscle lightness and, hence, did not result in darker muscle. However, exercise affected redness, albeit in a muscle-dependent manner: the semimembranosus muscle became less red, the LD muscle tended to become less red and the extensor carpi radialis muscle tended to become more red as a result of exercise (Dunne et al. 2005).

Lee et al. (2008) reported that the PUFA concentration and PUFA:SFA ratio of meat from loosehoused bulls were higher than those from tethered bulls, which is in accordance with our results where the PUFA proportion and PUFA:SFA ratio of the LD were higher in PAD than in IB bulls. This means that the meat of PAD bulls can be regarded as healthier meat that that of IB bulls. The amount of SFA in human diet can have a positive relationship with serum cholesterol levels and with deaths arising from coronary heart disease (e.g. Keys 1970). However, the intake of total dietary fat and the PUFA:SFA ratio in the diet seem to have a greater effect on blood cholesterol levels than does cholesterol itself (Seman and McKenzie-Parnell 1989). So it is recommended to reduce the fat intake to $30 \%$ of total energy intake and to increase the PUFA:SFA ratio above 0.4 (Wood et al. 2003).
In conclusion, compared with tethering in an insulated barn uninsulated or outdoor housing did not have any important effects on the meat quality of the Musculus longissimus dorsi of growing bulls. However, according to meat fatty acid profiles, outdoor housed bulls produced meat with a higher PUFA:SFA ratio than tethered bulls in an insulated barn.

Acknowledgements. Financial support from the Employment and Economic Development Centre for Northern Ostrobothnia is gratefully acknowledged. The authors would like to thank Mr. Lauri Jauhiainen for advice on statistical analyses and express their gratitude also to Mr. Matti Huumonen and his personnel for technical assistance and excellent care of the experimental animals.

\section{References}

AMSA 1978. Guidelines for Cookery and Sensory Evaluation of Meat. American Meat Science Association, National Livestock and Meat Board: Chicago, USA.

Bostian, M.L., Fish, D.L., Webb, N.B. \& Arey, J.J. 1985. Automated methods for determination of fat and moisture in meat and poultry products: collaborative study. Journal of Association of Official Analytical Chemists 68: 6877-6882.

Commission of the European Communities. 1982. Commission of the European Communities (Beef Carcass Classification) Regulations. Council Regulations 1358/80, 1208/81, 1202/82. Commission Regulations 2938/81, 563/82, 1557/82, Brussels.

Dunne, P. G., O'Mara, F. P., Monahan, F. J., French, P. \& Moloney, A. P. 2005. Colour of muscle of 18-month-old steers given long-term daily exercise. Meat Science 71: 219-229.

Dunne, P.G., Rogalski, J., Moreno, T., Monahan, F.J., French, P. \& Moloney, A.P. 2008. Colour, composition and quality of $M$. longissimus dorsi and $M$. extensor carpi radialis of steers housed on straw or concrete slats or accommodated outdoors on wood-chips. Meat Science 79: 700-708.

Essén-Gustavsson, B. 1996. Skeletal muscle adaptation with use and disuse. Comparative aspects between species. In: Proceedings of the $42^{\text {nd }}$ International Congress of Meat Science and Technology, Lillehammer, Norway.

French, P., Stanton, C., Lawless, F., O'Riordan, E.G., Monahan, F.J., Caffrey, P.J. \& Moloney, A.P. 2000. Fatty acid composition, including conjugated linoleic acid, of intramuscular fat from steers offered grazed grass, grass silage, or concentrate-based diets. Journal of Animal Science 78: 2849-2855.

Hornsey, H. C. 1956. The colour of cooked cured pork. I. Estimation of the nitric oxide-heam pigments. Journal of 


\section{AGRICULTURAL AND FOOD SCIENCE}

\section{Huuskonen, A. et al. Meat quality of bulls under different housing conditionsl}

Science of Food and Agriculture 7: 534-540.

Huuskonen, A., Jansson, S., Honkavaara, M., Tuomisto, L. Kauppinen, R. \& Joki-Tokola, E. 2010. Meat colour, fatty acid profile and carcass characteristics of Hereford bulls finished on grazed pasture or grass silage-based diets with similar concentrate allowance. Livestock Science 131: 125-129.

Huuskonen, A., Tuomisto, L., Joki-Tokola, E. \& Kauppinen, R. 2009. Animal performance and carcass characteristics of growing Hereford bulls under insulated, uninsulated and outdoor housing conditions in Northern Finland. Agricultural and Food Science 18: 16-26.

Jensen, L.R. \& Oksama, M. 1996. Influence of different housing systems on carcass and meat quality in young bulls. In: Proceedings of the $42^{\text {nd }}$ ICOMST, Lillehammer, Norway. p. 436-437.

Keys, A. 1970. Coronary heart disease in seven countries. Circulation 41, (Supplement 1): 1-211.

Lee, S.K., Panjono, Kang, S.M., Jung, Y.B., Kim, T.S., Lee, I.S., Song, Y.H. \& Kang, C.-G. 2008. Effects of tethering and loose housing on the meat quality of Hanwoo bulls. Asian-Australasian Journal of Animal Sciences 21: 1807-1814.

Lowe, D. E., Steen, R. W. J., Beattie, V. E. \& Moss, B. W. 2001. The effects of floor type systems on the performance, cleanliness, carcass composition and meat quality of housed finishing cattle. Livestock Production Science 69: 33-42.

Manninen, M., Sankari, S., Jauhiainen, J., Kivinen, T., Anttila, P. \& Soveri, T. 2008. Effects of outdoor winter housing and feeding level on performance and blood metabolites of suckler cows fed whole-crop barley silage. Livestock Science 115: 179-194.

Miller, R.K. 1994. Quality characteristics. In: Kinsman, D.M. Kotula, A.W. \& Breidenstein, B.C. (eds.). Muscle Foods: Meat, Poultry and Seafood Technology. New York, USA: Chapman \& Hall. pp. 296-332.

Muir, P.D., Deaker, J.M. \& Bown, M.D. 1998a. Effects of forage- and grain-based feeding systems on beef quality: A review. New Zealand Journal of Agricultural Research 41: 623-635.

Muir, P.D., Smith, N.B., Wallace, G.J., Cruickshank, G.J. \& Smith, D.R. 1998b. The effect of short-term grain feeding on liveweight gain and beef quality. New Zealand Journal of Agricultural Research 41: 517-526.

Priolo, A., Micol, D. \& Agabriel, J. 2001. Effects of grass feeding systems on ruminant meat colour and flavour. A review. Animal Research 50: 185-200.
Razminowicz, R.H., Kreuzer, M. \& Scheeder, M.R.L. 2006. Quality of retail beef from two grass-based production systems in comparison with conventional beef. Meat Science 73: 351-361.

Realini, C.E., Duckett, S.K., Brito, G.W., Dalla Rizza, M. \& De Mattos, D. 2004. Effect of pasture vs. concentrate feeding with or without antioxidants on carcass characteristics, fatty acid composition, and quality of Uruguayan beef. Meat Science 66: 567-577.

Rowe, A., Macedo, F.A.F., Visentainer, J.V., Souza, N.E. \& Matsushita, M. 1999. Muscle composition and fatty acid profile in lambs fattened in drylot or pasture. Meat Science 51: 283-288.

Seman, D.L. \& McKenzie-Parnell, J.M. 1989. The nutritive value of meat as a food. In: Purchas, R.W., ButlerHogg, B.W. \& Davies, A.S. (eds.). Meat Production and Processing. Occasional Publication No. 11, New Zealand Society of Animal Production. pp. 13-28.

Sweeney, R.A. \& Rexroad, P.R. 1987. Comparison of LECO ${ }^{8}$ FP-228 "Nitrogen Determinator" with AOAC copper catalyst kjeldahl method for crude protein. Journal of Association of Official Analytical Chemists 70: 1028-1035.

Tuomisto, L., Ahola, L., Martiskainen, P., Kauppinen, R. \& Huuskonen, A. 2008. Comparison of time budgets of growing Hereford bulls in an uninsulated barn and in extensive forest paddocks. Livestock Science 118: 44-52.

Tuomisto, L., Huuskonen, A., Ahola, L. \& Kauppinen, R. 2009. Different housing systems for growing dairy bulls in Northern Finland - effects on performance, behaviour and immune status. Acta Agriculturae Scandinavica, Section A, Animal Science 59: 35-47.

Uusi-Kämppä, J., Jauhiainen, L. \& Huuskonen, A. 2007. Phosphorus and nitrogen losses to surface waters from a forested feedlot for bulls in Finland. Soil Use and Management 23: Supplement 1: 82-91.

Varnam, A.H. \& Sutherland, J.P. 1995. The colour of meat. In: Meat and Meat Products - Technology, Chemistry and Microbiology. London, UK: Chapman and Hall.

Vestergaard, M., Oksbjerg, N. \& Henkel, P. 2000. Influence of feeding intensity, grazing and finishing feeding on muscle fibre characteristics and meat colour of semitendinous, longissimus dorsi and supraspinatus muscles in young bulls. Meat Science 54: 177-185.

Wood, J.D., Richardson, R.I., Nute, G.R., Fisher, A.V., Campo, M.M., Kasapidou, E., Sheard, P.R. \& Enser, M. 2003. Effects of fatty acids on meat quality: a review. Meat Science 66: 21-32. 